\title{
The Effects of Taxation on the Location Decision of Multinational Firms: M\&A vs. Greenfield Investments
}

\author{
Shafik Hebous \\ Martin Ruf \\ Alfons Weichenrieder
}

CESIFO WORKING PAPER NO. 3076

CAtegory 1: Public Finance

JUNE 2010

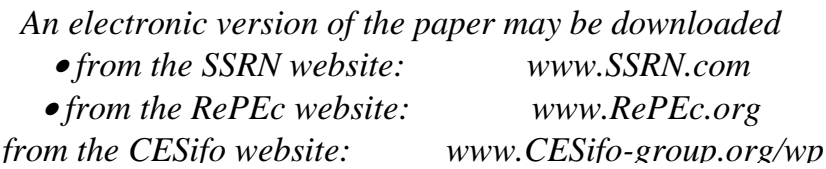




\title{
The Effects of Taxation on the Location Decision of Multinational Firms: M\&A vs. Greenfield Investments
}

\begin{abstract}
In this study, we estimate the impacts of differences in international tax rates on the probability of choosing a location for an affiliate of a multinational firm. In particular, we distinguish between the tax sensitivity of Greenfield and M\&A investments. Based on a novel firm-level dataset on German outbound FDI, we find evidence that location decisions of M\&A investments are less sensitive to differences in tax rates than location decisions of Greenfield investments. According to our logit estimates, and after controlling for firm and country-specific characteristics, the tax elasticity for Greenfield investments is negative and in absolute value significantly larger than that associated with M\&A investments. This finding is consistent with a (partial) capitalisation of taxes in the acquisition price when the FDI project takes the form of M\&A.
\end{abstract}

JEL-Code: H25, H73, F23.

Keywords: FDI, corporate taxation, location, M\&A, Greenfield.

Shafik Hebous

Faculty of Economics and Business Admin.

Goethe University Frankfurt / Germany

hebous@wiwi.uni-frankfurt.de

\author{
Martin Ruf \\ University of Mannheim \\ Germany \\ martin.ruf@bwl.uni-mannheim.de
}

\author{
Alfons Weichenrieder \\ Goethe University Frankfurt / Germany \\ a.weichenrieder@em.uni-frankfurt.de
}

May 27, 2010

We are grateful to Heinz Herrmann, Beatrix Stejskal-Passler, Alexander Lipponer and the research centre of Deutsche Bundesbank for the kind support. We thank Michael P. Devereux, Carsten Eckel, Clemens Fuest, seminar participants at the Oxford Centre for Business Taxation, Max Planck Institute for Intellectual Property, Competition and Tax Law, and two anonymous referees for helpful suggestions and comments. We are indebted to the ZEW Mannheim especially Christoph Spengel and Christina Elschner for providing us data on the effective tax rates. The usual disclaimer applies. 


\section{Introduction}

The role of taxation in explaining international allocation of investment has been a subject of immense theoretical and empirical scrutiny. Undoubtedly, several factors affect the location decision of a multinational firm. The tax system of the potential host economy is one of these factors positioning this issue on the intersection of several branches of economies: public finance, international economics and international business.

Earlier empirical studies based on aggregate figures on foreign direct investment (FDI) suggest that high taxes negatively impact the flow of FDI; de Mooij and Ederveen (2003) and Hines (1999). Recent empirical works exploit data at the firm level to estimate the effects of taxes on the decision where to allocate the affiliate of the multinational firm. By relying on microeconomic data, these studies can provide information on the impact of taxes on behavioural responses of multinational firms to international differences in taxation and adequately account for differences across firms and industries. However, most existing empirical studies treat FDI modes as homogenous projects missing one crucial piece of information, namely, the distinction between Mergers and Acquisitions (M\&A) and Greenfield investment projects (new ventures). ${ }^{1}$

In this study, we progress to account for the mode of investment in estimating the effect of differences in international tax rates on the probability of choosing a location for an affiliate of a multinational firm. Specifically, there are reasons to expect that the location decision of Greenfield investments is more sensitive to differences in international tax rates than the location decision of M\&A projects. First, if the potential M\&A project is located in a high tax country, a part of taxes might be capitalised reducing the acquisition price. This capitalisation effect is less pronounced in the case of a Greenfield investment and suggests that M\&A investments should react less to high taxes than Greenfield investments do. Second, M\&A decisions depend on the availability of appropriate targets. In principle, the set of potential locations for establishing a new plant might be larger than that of potential locations of target firms to be acquired. This may make the multinational firm less constrained in optimising over the location decision of the new venture.

In our econometric analysis, we employ detailed firm-level data on German outbound FDI covering about 3600 firms in the period from 2005 to 2007 . The valuable feature of this dataset is that since 2005 the German investor has to report whether a new FDI project is a Greenfield or M\&A project. This enables us to directly identify the mode of investment at the entry. In our sample, 34 percent of firms enter the host economy as a Greenfield project. The US is the largest receiver of new FDI entries with a share of about 11 percent of total German new outbound FDI projects.

Our main findings are summarised as follows. First, if we do not distinguish between the modes of entry, high tax rates reduce the probability of the location to be chosen by a German FDI investor for its new affiliate. This find-

\footnotetext{
${ }^{1}$ See Devereux (2007) for a survey.
} 
ing is in line with results by Devereux and Griffith (1998) on the location of US multinationals abroad. Our second finding however reveals that Greenfield investments are significantly more elastic to international taxation than M\&A investments. According to our logit estimates and after controlling for firm and country-specific characteristics, an increase in the statutory corporate income tax rate of 10 percent reduces the probability of choosing a country to host a Greenfield investment by about 6.4 percent. The tax elasticity for M\&A investments however, although negative, is significantly smaller and only about 3.6 percent. Our study is the first to document this empirical finding using outbound microeconomic data. The notable exception linked to our study is Swenson (2001) who examines the composition of FDI within the US and reports that Greenfield activities are more deterred than M\&A activities from investing in high tax states. ${ }^{2}$ The idea that the impact of taxation may depend on the modes of FDI traces back to Auerbach and Hassett (1991) who argue that tax reforms can alter the incentive of investing in acquisition of old capital versus investing in new capital. Becker and Fuest (2008) present a theoretical model of tax competition in which an increase in the tax rate raises the number of $M \& A$ investments and lowers the number of Greenfield investments. Huizinga and Voget (2009) examine the impacts of double taxation on the organisational structure following cross-border M\&A activities. They find that countries with high levels of international double taxation are less inclined to host the new parent firm after the merger or acquisition has occurred. ${ }^{3}$

Recent contributions in the literature on the theory of international trade predict that firm and project-specific characteristics play the major role in determining the mode of entry. Nocke and Yeaple (2008) and Raff et al. (2009) show that more productive firms tend to enter the foreign market as a Greenfield rather than M\&A investment. In line with this result, Andersson and Svensson (1994) find that high technological skills and research and development intensity favour Greenfield operations. Neary (2007) introduces an oligopolistic market structure in a general equilibrium framework and shows that firms acquire their high cost revivals. In Nocke and Yeaple (2007), firms involve in M\&A activities to complement their abilities.

From a policy perspective, our finding that high tax countries are less attractive particularly for Greenfield investments suggests that high tax countries miss the chance of collecting additional tax revenues mainly because new Greenfield projects are allocated to low tax countries. Furthermore, the different impacts of high tax rates on the composition of FDI is also of economic interest as Greenfield investments and M\&A can have different implications on the host economy. M\&A activities involve a change in the pattern of ownership rights but to a less extent involve international reallocation of capital or an increase in production capacity or labour demand. Furthermore, the pattern of productivity spillovers from multinational affiliates to domestic firms through knowledge spillovers and changing the competition structure of the host economy may differ between

\footnotetext{
${ }^{2}$ Swenson (2001) finds that high taxes have a positive but insignificant effect on M\&As.

${ }^{3}$ The influence of taxes on the ownership of foreign affiliates has recently been emphasized by Desai and Hines (2003) and Becker and Fuest (2010).
} 
M\&A and Greenfield projects; Balsvik and Haller (2007).

This study proceeds as follows. In section two, we present our empirical approach and describe the German firm-level FDI dataset. We report the main results in section three, and present a robustness analysis in section four. Finally, we conclude in section five.

\section{Empirical methodology and data}

\subsection{Investigation approach}

Our econometrical analysis is cross-sectional focusing on firms at the entry and is based on a rich literature on FDI location choice. The firm selects the location associated with the highest expected profit. ${ }^{4}$ Profit functions $\left(\Pi_{i}\right)$ associated with each location $i=1,2, \ldots, n$ are:

$$
\Pi_{i}=\left(1-\tau_{i}\right)\left[R_{i}-C_{i}\right]-I_{i}^{j}\left(\tau_{i}\right),
$$

where $j$ denotes either a Greenfield or a M\&A investment. The variable $\tau_{i}$ is the corporate tax rate in location $i . R_{i}$ is revenue and $C_{i}$ is the cost function which can depend on several factors such as: output, cost of labour, agglomeration and other external economies effects etc. The term $I_{i}^{j}\left(\tau_{i}\right)$ captures the initial cost of the FDI in the case of Greenfield projects and the purchase price in the case of M\&A projects. The optimal levels of output can be derived by solving the system of first order conditions. Optimal profits $\left(\Pi_{i}^{*}\right)$ can be computed by substituting the optimal levels of output in the corresponding profit functions. Ultimately, however, our focus here is on the effects of taxation on location decisions of $\mathrm{M} \& \mathrm{~A}$ versus Greenfield investments.

High taxes in the host economy lower future cash flows of the cross-border investment in the case of M\&A as well as the case of Greenfield projects. Hence, high taxes deter both types of FDI. However, in the case of a M\&A project the acquisition price is a function of the tax rate. The value of a firm is the present value of the cash payoffs that the claim holders of the firm receive; Healy and Palepu (2007). Corporate taxation reduces the value of a firm; Modigliani and Miller (1963). Consequently, a high tax rate may reduce the final price paid by the buyer for a potential firm. Huizinga, Voget, and Wagner (2008) provide empirical evidence on a capitalisation effect of taxes in takeover premiums. Hence, if part of the tax is capitalised in the purchase price then $\frac{\partial I_{i}^{M \& A}\left(\tau_{i}\right)}{\partial \tau_{i}}<0$. This capitalisation effect however is expected to be smaller in the case of a Greenfield investment since many mobile capital goods might be purchased at world prices. Thus, the capitalisation of taxes in the acquisition price suggests that the impact of taxes on the location decision is mitigated in the case of M\&A investments as compared to the case of Greenfield investments.

Empirically, we observe the binary latent variable:

\footnotetext{
${ }^{4}$ Since we observe a FDI decision, we focus on the decision where to invest rather than the decision whether to stay home or go abroad. See Marksuen (2002) for a general equilibrium treatment of these decisions.
} 


$$
y_{k, l}=\left\{\begin{array}{l}
1 \text { if } \Pi_{k, l}^{*}>\Pi_{k, i}^{*}, i=1,2, \ldots, n \text { and } l \neq i \\
0 \text { otherwise }
\end{array}\right.
$$

where the subscript $k$ denotes firms. The profitability of location $l$ depends inter alia on the statutory corporate income tax rate in location $l\left(\tau_{l}\right)$ :

$$
\Pi_{k, l}^{*}=\alpha+\beta \tau_{l}+\gamma\left(M \& A_{k} * \tau_{l}\right)+\mathbf{\Phi} \mathbf{x}_{k, l}+\epsilon_{k, l}
$$

where $\alpha$ is an intercept, $\beta$ and $\gamma$ are the coefficients of interest, $\boldsymbol{\Phi}$ is the vector of coefficients corresponding to the controls and $\epsilon_{k, l}$ is a residual. To investigate whether or not the two modes of investment react differently to taxes, we include the interaction term $M \& A^{*} \tau$, where $M \& A$ is a dummy that takes the value 1 if the investment takes the form of M\&A and zero if the investment is a Greenfield project. The multiplication of the $M \& A$ dummy and the tax rate is required to compute interaction effects. ${ }^{5}$ The vector $\mathbf{x}_{k, l}$ is a vector of alternative-specific controls that includes country-specific controls, i.e. controls that vary across countries but not firms, as well as firm-country controls that vary across countries but are firm specific. In some specifications, we also take into account industry-specific effects.

The probability of firm $k$ choosing location $l$ is given by:

$$
P_{k, l}=\frac{e^{\Pi_{k, l}^{*}}}{\sum_{i=1}^{n} e^{\Pi_{k, i}^{*}}}
$$

This logit model is estimated by maximum likelihood. The tax variable $\tau_{l}$ is central in our analysis and its impact is expected to be negative and larger in absolute value for Greenfield than M\&A investments. The identification is based on cross-sectional variation in tax rates. Data on taxes are taken from Mintz and Weichenrieder (forthcoming). Table (1) displays the statutory corporate income tax rates for the countries in our sample. In 2006 for example, it exhibits a minimum rate of 12.5 percent in Ireland and a maximum rate of 40.7 percent in Japan.

The vector $\mathbf{x}_{k, l}$ includes several variables that are related to the probability of locating an affiliate in a host economy. (1) The previous presence of a firm in location $l$ is captured by the number of affiliates already operating in the host economy (no. affiliates). The presence of a firm in an economy may increase the probability of selecting that economy again. (2) The total fixed and intangible assets invested by the parent firm in location $l$ (total assets) accounts for the size of the prior investment of the parent firm in location $l$. (3) The level of development of the host economy is captured by the GDP per capita (gdp capita). (4) The market size of the host economy is captured by

\footnotetext{
${ }^{5}$ However, the dummy $M \& A$ per se without interaction is not included in the regression because it does not vary across the alternatives available for a firm. If for example the German parent acquires a firm in a country then the dummy $M \& A$ takes the value 1 and also the variable $y$ takes the value 1 for this country-firm observation. However, the M\&A dummy takes the value 1 also for all other country-year observations corresponding to this location choice (for which the variable $y$ takes the value zero).
} 
Table 1: Statutory corporate income tax rates, percent

\begin{tabular}{lccclccc}
\hline Country & 2005 & 2006 & 2007 & Country & 2005 & 2006 & 2007 \\
\hline \hline Argentina & 35 & 35 & 35 & Malaysia & 28 & 28 & 27 \\
Australia & 30 & 30 & 30 & Malta & 35 & 35 & 35 \\
Austria & 25 & 25 & 25 & Mexico & 30 & 29 & 28 \\
Belgium & 34 & 34 & 34 & Morocco & 35 & 35 & 35 \\
Brazil & 34 & 34 & 34 & Netherlands & 31.5 & 29.6 & 25.5 \\
Bulgaria & 15 & 15 & 10 & New Zealand & 33 & 33 & 33 \\
Canada & 34.4 & 34.2 & 34.1 & Nigeria & 30 & 30 & 30 \\
Chile & 17 & 17 & 17 & Norway & 28 & 28 & 28 \\
China & 33 & 33 & 33 & Philippines & 32 & 35 & 35 \\
Colombia & 35 & 35 & 34 & Poland & 19 & 19 & 19 \\
Croatia & 20.3 & 20.3 & 20 & Portugal & 27.5 & 27.5 & 25 \\
Czech & 26 & 24 & 24 & Romania & 16 & 16 & 16 \\
Denmark & 28 & 28 & 28 & Russia & 24 & 24 & 24 \\
Egypt & 20 & 20 & 20 & Saudi Arabia & na & 20 & 20 \\
Finland & 26 & 26 & 26 & Singapore & 20 & 20 & 20 \\
France & 33.8 & 33.3 & 33.3 & Slovakia & 19 & 19 & 19 \\
Greece & 32 & 29 & 25 & Slovenia & 25 & 25 & 23 \\
Hong Kong & 17.5 & 17.5 & 17.5 & South Africa & 37.8 & 36.9 & 36.9 \\
Hungary & 16 & 16 & 16 & Spain & 35 & 35 & 32.5 \\
India & 36.6 & 33.7 & 34 & Sweden & 28 & 28 & 28 \\
Indonesia & 30 & 30 & 30 & Switzerland & 21.3 & 21.3 & 21.3 \\
Ireland & 12.5 & 12.5 & 12.5 & Taiwan & 25 & 25 & 25 \\
Italy & 37.3 & 37.3 & 37.3 & Thailand & 30 & 30 & 30 \\
Japan & 40.7 & 40.7 & 40.7 & Turkey & 30 & 30 & 20 \\
Kenia & 30 & 30 & 30 & UK & 30 & 30 & 30 \\
Korea & 27.5 & 27.5 & 27.4 & Ukraine & 25 & 25 & 25 \\
Lithuania & 15 & 15 & 15 & USA & 39 & 39 & 38.6 \\
Luxembourg & 30.4 & 29.6 & 29.6 & Venezuela & 34 & 34 & 34 \\
\hline \hline
\end{tabular}

its population (population). The level of development and market size both are expected to have positive effects on the probability of entering. (5) The local labour market condition is captured by the labour freedom component of the Heritage index of economic freedom (labour freedom). This proxy is computed based on four factors: minimum wages, rigidity of hours, difficulty of firing redundant employees and cost of firing redundant employees. ${ }^{6}$ The labour freedom index is expected to be positively related to the probability of choosing a location $l$; the higher the flexibility of the labour market the higher the probability of entering the economy. ${ }^{7}$ (6) The distance between Germany

\footnotetext{
${ }^{6}$ See Miller and Holmes (2009) for detailed information on the Heritage index.

${ }^{7}$ Some studies incorporate the average wage as a proxy for the labour market situation. However, in most studies this variable turned out to be insignificant as for example in Devereux and Griffith (1998) and Head and Mayer (2004). Furthermore, unfortunately, data on average
} 
and the location of the FDI project (distance). The inclusion of this variable is in the tradition of the gravity literature. It captuers transport (trade) costs and may also capture investors' information on market conditions in the host economy. Distance is typically associated with a negative estimated coefficient. (7) The openness of the host economy to international trade is captured by the ratio (imports $s_{l}+$ exports $\left.s_{l}\right) / g d p_{l}$ (openness). This proxy may capture two opposite aspects. For example, the tariff-jumping argument suggests that the probability of entering a relatively closed economy is rather high in order to get access to the market. At the same time, economies that are more open to international trade may be more open to international investments. (8) The quality of institution is captured by a corruption index (corruption). We employ the Corruption Perception Index of Transparency International. We redefine it such that a high value of this index indicates a high level of corruption. Further, we include industry dummies in some specifications. These dummies account for difference across industries and potential industry-specific economies of scales considerations. All level variables are expressed in terms of natural logarithm. In the robustness analysis, we examine the effects of the effective tax rate and further country-specific characteristics such as the R\&D intensity and the ratio of market capitalisation of listed firms. The reader is referred to the data appendix for a detailed description and the sources of the variables that are used in our study.

\subsection{Firm data and descriptive statistics}

The German foreign trade and payments regulation obliges all German firms and individuals investing abroad and satisfying the reporting requirements to report key information such as balance sheet items as well as economic sectors of the parent firm and its affiliates. In contrast to several firm-level data sources, a valuable feature of this dataset is the inclusion of the entire population of FDI firms rather than being exclusive to listed or "big" firms. Since 2005, Ger-

man investors are required to report whether a new investment is a Greenfield or M\&A project. ${ }^{8}$ This is a novel piece of information that enables us to directly identify the mode of entry and conduct our empirical investigation. We exclude from our sample banks, financial and non-profit institutions since such institutions face special tax treatments.

The data cover the years 2005, 2006 and 2007. Figure (1) displays the number of new entries in each year. In total, 2321 new cross-border M\&A projects and 1306 Greenfield investments are reported. In 2005, Greenfield investments constitute about 35 percent of total new entries. A similar pattern occurs in 2006 and 2007 with a share of 36 and 38 percent respectively.

wages are not available for many countries in our sample.

${ }^{8}$ The investor has to check in the reporting form one of four possible options of outbound FDI: (1) new entry Greenfield project, (2) new entry M\&A project, (3) already existing firm (the same firm has been reported in the last year), or (4) first time satisfying the reporting requirements (the firm existed last year but has not been reported). The first two options are the new entrants. Further details on the reporting requirements and German FDI dataset can be found in Lipponer (2008). 


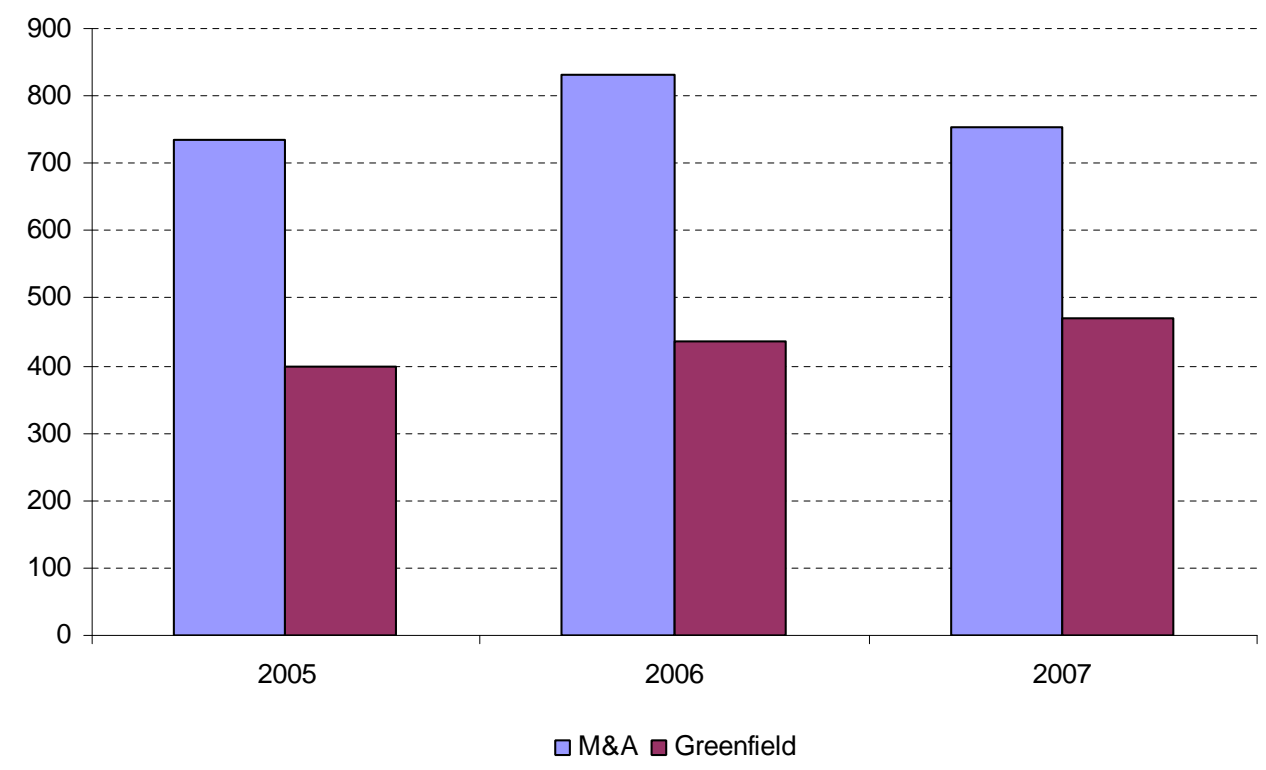

Figure 1: Number of new investments

Table (2) shows that 63 percent of new entries take place in Europe. The geography of the new entrants reveals that the USA receives the largest share of the number of new entries (10.6 percent). Although 67.1 percent of entries in the USA are M\&A investments, the USA has the second largest share of worldwide Greenfield entries (11.1 percent). China is the largest receiver of Greenfield investments with a share of about 15.9 percent of the total German Greenfield entries worldwide. Furthermore, table (2) shows the regional pattern of FDI destinations. Several countries that share a common border with Germany such as Austria, Switzerland, the Netherlands and Poland are among the top 10 recipients of new FDI projects. This indicates to the widely recognised border effect and speaks for the inclusion of a variable measuring the distance between Germany and the final destination of the FDI project.

In terms of the size of the new investment, figure (2) shows that the average fixed and intangible assets of a FDI project varies across the modes of entry and locations. For example, in 2007 the average asset ratio of a M\&A project allocated out of Europe amounts to over 60 million Euro whereas this average for a M\&A project within Europe is about 23 million Euro.

Table (3) provides the means, standard deviations, $5^{\text {th }}$ percentiles, and $95^{t h}$ percentiles of the variables that are used in our study according to both types of FDI. The figures are similar across both modes of investments. We report the coefficients of correlation between the variables in table (4). The statutory 
Table 2: German outbound new FDI entries, 2005-2007 (percent)

\begin{tabular}{rrrrr}
\hline & $\begin{array}{r}\text { Share in } \\
\text { total new } \\
\text { entry }\end{array}$ & $\begin{array}{r}\text { MA share } \\
\text { in new } \\
\text { entrants }\end{array}$ & $\begin{array}{r}\text { MA share } \\
\text { in worldwide } \\
\text { MA entrants }\end{array}$ & $\begin{array}{r}\text { Greenfield share } \\
\text { in worldwide } \\
\text { Greenfield entrants }\end{array}$ \\
\hline \hline Europe & 63 & 73 & 66.9 & 54.4 \\
Out of Europe & 37 & 61.4 & 33.1 & 45.6 \\
Austria & 5.4 & 71.0 & 5.6 & 5.0 \\
Belgium & 2.5 & 84.0 & 3.1 & 1.3 \\
China & 7.9 & 36.8 & 4.2 & 15.9 \\
France & 6.4 & 83.3 & 7.8 & 3.4 \\
Italy & 3.6 & 83.0 & 4.3 & 1.9 \\
Poland & 3.5 & 59.2 & 2.9 & 4.5 \\
Russia & 2.3 & 38.2 & 1.3 & 3.5 \\
Switzerland & 4.2 & 77.6 & 4.7 & 3.6 \\
The Netherlands & 4.8 & 76.5 & 5.4 & 3.8 \\
UK & 8.7 & 86.1 & 10.9 & 11.1 \\
USA & 10.6 & 67.1 & 10.4 & \\
\hline \hline
\end{tabular}

Note: The reported figures are shares in the total number of entries. The table includes only the top 10 important host economies.

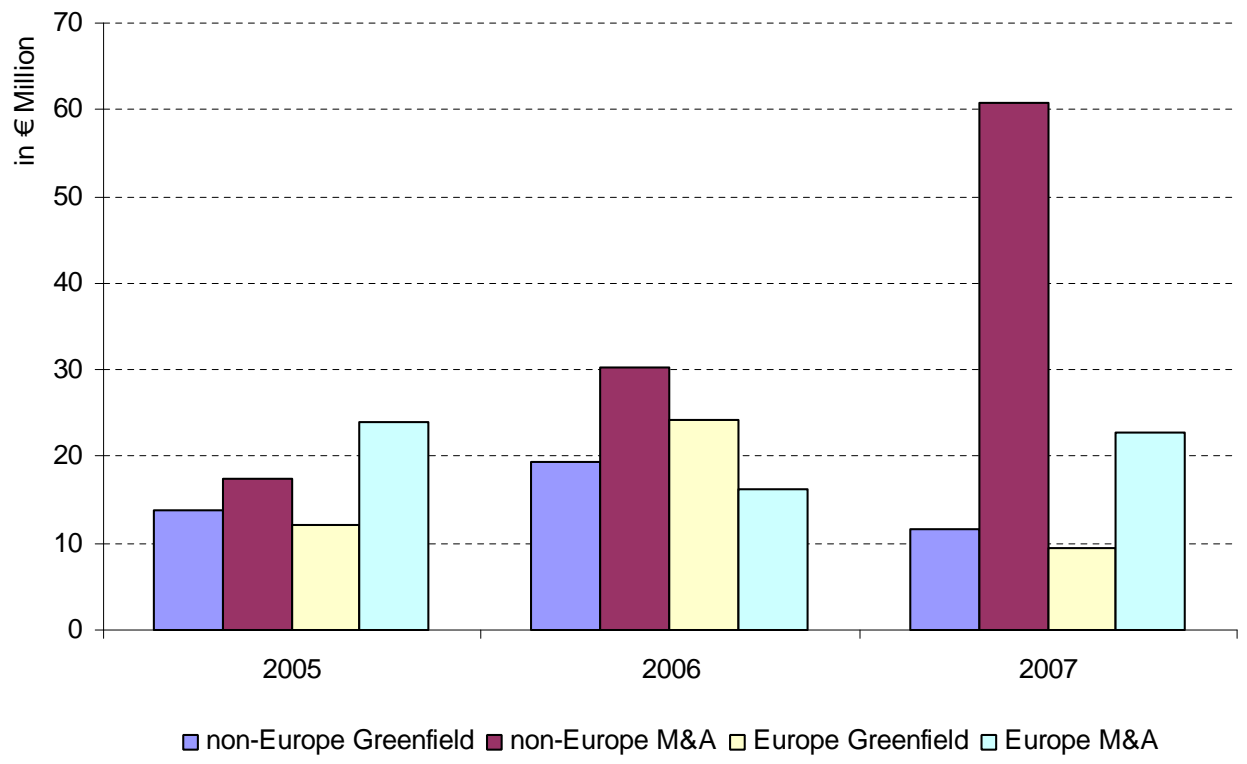

Figure 2: Average fixed and intangible assets 
tax rate is highly positively correlated with the effective average tax rate (0.94). The correlation between the corruption level and the statutory tax rate is very low.

Table 3: Descriptive statistics

\begin{tabular}{lllll}
\hline & mean & sd. & 5 th Percentile & 95th percentile \\
\hline \hline statutory tax rate & 0.27 & 0.06 & 0.16 & 0.37 \\
no. affiliates & 0.16 & 0.42 & 0 & 1.09 \\
total assets & 1.31 & 3.21 & 0 & 9.59 \\
gdp capita & 9.85 & 0.76 & 8.31 & 10.76 \\
population & 16.91 & 1.62 & 14.51 & 19.51 \\
openess & 1.05 & 0.82 & 0.3 & 3.02 \\
distance & 7.86 & 1.19 & 6.14 & 9.41 \\
labour freedom & 0.65 & 0.16 & 0.4 & 0.95 \\
corruption & -5.77 & 2.37 & -2.40 & -9.39 \\
market capitalisation & 0.96 & 0.81 & 0.27 & 2.10 \\
RD / GDP & 1.31 & 0.92 & 0.11 & 3.43 \\
market potential & 28.86 & 0.64 & 27.40 & 30.13 \\
effective tax rate & 0.27 & 0.08 & 0.16 & 0.42 \\
\hline \hline
\end{tabular}

Note: The reader is referred to the data appendix for detailed description of the variables. 


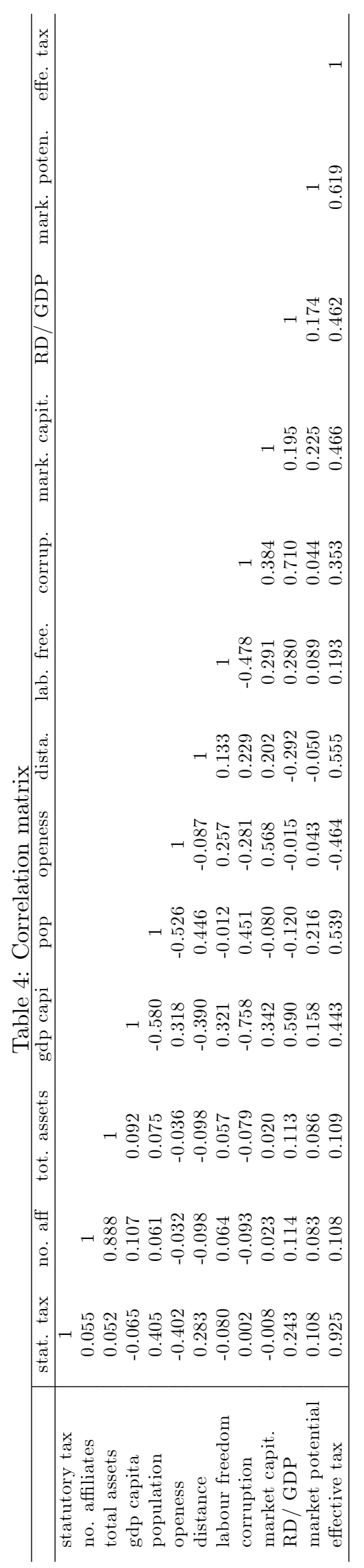




\section{Empirical results}

Table (5) presents our main estimation results. The signs of the estimated coefficients on country-specific variables provide the directions of the effects of these variables on the odds ratio of the probability of choosing a location $l$. In columns (1) to (3) we constrain the effects of taxation to be the same across modes of FDI. The difference between column (1) and (2) is the inclusion of year dummies in column (2). To capture potential industry-specific location preferences, we re-estimate the benchmark model but include industry-specific dummies. The results are reported in column (3). As expected, the coefficient on the tax rate is negative and significant in all specifications. This finding is in line with studies that consider a similar exercise on the location decision of affiliates abroad; Buettner and Ruf (2007) and Egger et al. (2009). Also, this finding is in line with results obtained from aggregate FDI flow figures; a recent example is Djankov et al. (2009).

However, such specifications ignore the heterogeneous modes of investment. In the remaining specifications in table (5), we allow taxation to have different impacts depending on the mode of investment. In columns (4) to (6) in table (5), the estimated coefficients on the tax rate indicate a negative response of Greenfield investments (the reference group) to high taxes. The coefficients in non-linear models are not equivalent to elasticities. Marginal effects in nonlinear models are conditional on all independent variables included on the model. We compute the corresponding elasticities and report the results in table (6). The estimated elasticities are very similar across specifications within a sample. Therefore, we report the results for one specification per sample, namely elasticities corresponding to the specification including year-dummies but not industry-dummies. For example, as indicated in column (3) of table (6), we find that an increase in the statutory corporate income tax rate of 10 percent (for instance from $35 \%$ to $38.5 \%$ ) reduces the probability of choosing a country to host a Greenfield investment by 6.4 percent.

Yet, the elasticity of the interaction term $\tau * M \& A$ reported in column (2) of table (6) is positive and significant (0.30), but cannot be necessarily interpreted as a clear indication that $M \& A$ investments react less sensitively to international differences in taxation than Greenfield investments do. As stressed in $\mathrm{Ai}$ and Norton (2003), the interpretation of the estimated elasticity of the interaction term in non-linear models is not straightforward. To disentangle the estimated tax impact on M\&A investments, the full interaction effect should be computed. The full interaction effect is a function of the cross-partial derivative of the expected value of the dependent variable. Hence, its statistical significance depends on the significance of the whole cross-derivative, and cannot be tested with the usual $t$-test on the interaction term.

To be sure, we compute the full interaction effect as a function of the predicted probability and the corresponding $z$-statistics. Figure (3) plots the results. The interaction effects are positive and significant for almost all observa-

tions confirming the hypothesis that Greenfield investments react more strongly to high tax rates than M\&A investments. The interaction effects are insignifi- 
cant for few observations in the left group of firms whose predicted probability is rather small (on the left of the lower panel of figure 3). In line with the estimated positive interaction effects, column (4) of table (6) shows that the estimated tax elasticity of M\&A investments is 0.36 ; i.e. only about half of the tax elasticity of Greenfield investments (0.64 in column 3).

Additionally, in the remaining specifications in table (5) we investigate whether or not the control variables may have different influences on the location probability depending on the mode of entry. We concentrate the analysis on either the sample of Greenfield investments (columns 7 to 9) or the sample of M\&A projects (columns 10 to 12). The corresponding elasticities are reported in table (6) in columns (3) and (4), respectively. According to the results, an increase in the corporate income tax rate of a 10 percent reduces the probability of choosing a country to host a Greenfield investment by about 6.4 percent. For the M\&A sample, the coefficient on the tax rate although significant is rather small. For instance, an increase in the statutory corporate income tax rate of 10 percent reduces the probability of a country receiving a M\&A investment by 3.6 percent. The negative M\&A tax elasticity is consistent with recent studies that use aggregate figures on M\&A; Di Giovanni (2005) and Coeurdacier et al. (2009). Thus, our results suggest that M\&A investments are less discouraged to locate their affiliates in high tax economies than Greenfield investments do.

Concerning the remaining control variables, based on the results reported in table (5) and the elasticities reported in table (6), the presence of affiliated firms and their previous year total fixed investment in assets in a location increase the probability of entering this location again in all specifications. Additionally, the size (population) and the level of development of the host economy (gdp per capita) both have positive significant effects on the odds ratio of the location probability. Distance has a negative effect as expected. ${ }^{9}$ The openness of the economy to international trade is a positive determinant of the location probability of FDI in the whole sample. However, the sub-sampling indicates that the openness variable seems to play particularly a significant role in the location decision of Greenfield investments. Although the labour freedom index has the expected positive sign in all specifications it is insignificant. ${ }^{10}$ Further, as in Javorcik and Wei (2009) we find that a decrease in the level of corruption, as captured by the Transparency International index, increases the probability of selecting a location for an affiliate. However, this index loses its significance in the Greenfield sample (columns 7 to 9 ). This may indicate that different modes of investment may accept different conditions in the host economy.

\footnotetext{
${ }^{9}$ Hijzen et al. (2008) examine in details the role of trade costs for M\&A activities.

${ }^{10}$ Dewit et al. (2009) find based on aggregate figures that the level of employment protection deters inward FDI flows.
} 


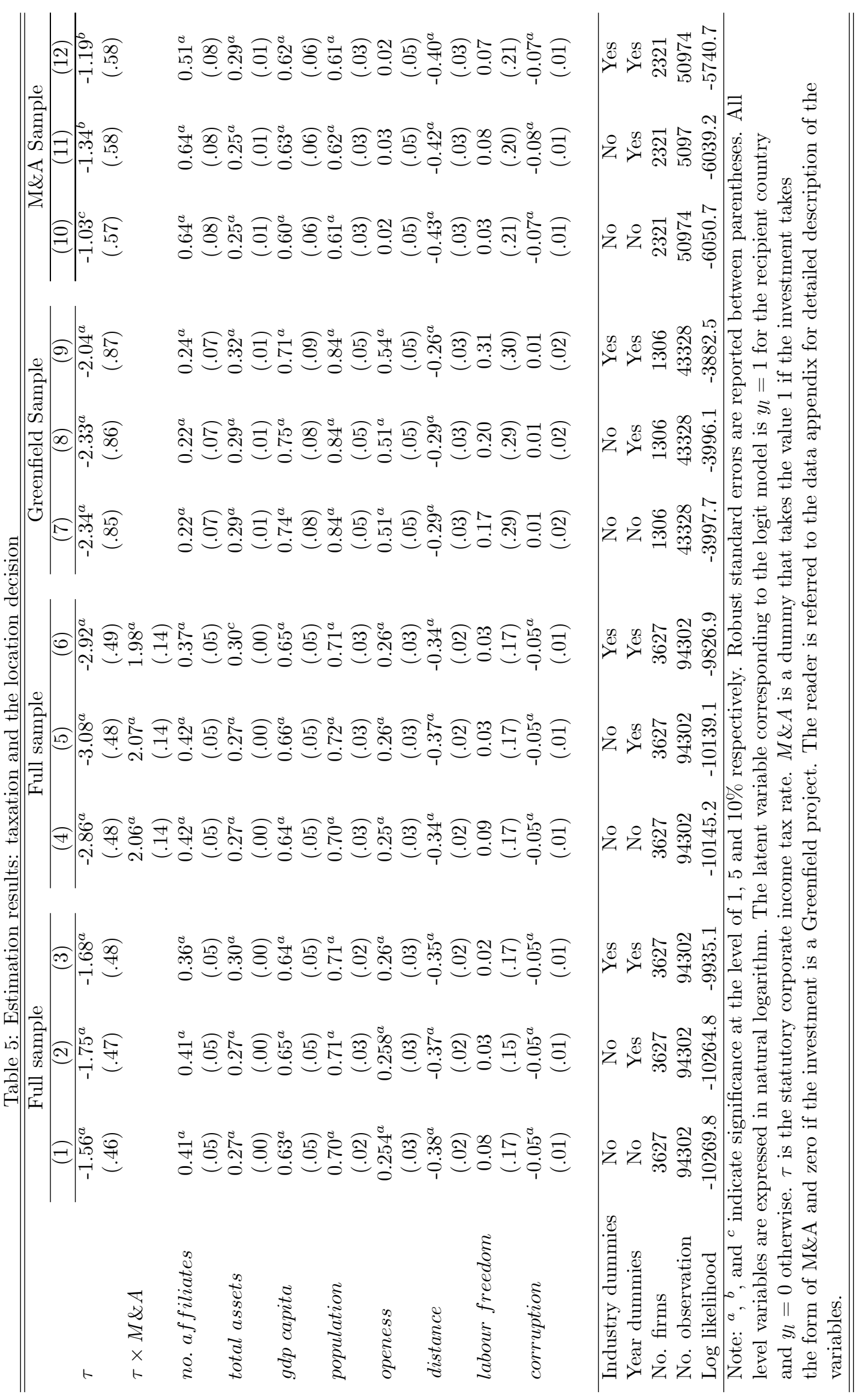


Table 6: Estimated elasticities

\begin{tabular}{|c|c|c|c|c|}
\hline Elasticity & $\begin{array}{c}\text { Full } \\
\text { sample }\end{array}$ & $\begin{array}{c}\text { Full } \\
\text { sample }\end{array}$ & $\begin{array}{l}\text { Greenfield } \\
\text { Sample }\end{array}$ & $\begin{array}{c}\text { M\&A } \\
\text { Sample }\end{array}$ \\
\hline$\tau$ & $\begin{array}{c}-0.47^{a} \\
(.12)\end{array}$ & $\begin{array}{c}-0.83^{a} \\
(.13)\end{array}$ & $\begin{array}{c}-0.64^{a} \\
(.32)\end{array}$ & $\begin{array}{c}-0.36^{b} \\
(.15)\end{array}$ \\
\hline$\tau \times M \& A$ & & $\begin{array}{c}0.30^{a} \\
(.02)\end{array}$ & & \\
\hline no. af filiates & $\begin{array}{l}0.06^{a} \\
(.00)\end{array}$ & $\begin{array}{l}0.06^{a} \\
(.00)\end{array}$ & $\begin{array}{l}0.03^{b} \\
(.01)\end{array}$ & $\begin{array}{l}0.10^{a} \\
(.01)\end{array}$ \\
\hline total assets & $\begin{array}{r}0.35^{a} \\
(.01)\end{array}$ & $\begin{array}{c}0.36^{a} \\
(.01)\end{array}$ & $\begin{array}{l}0.39^{a} \\
(.01)\end{array}$ & $\begin{array}{l}0.32^{a} \\
(.01)\end{array}$ \\
\hline gdp capita & $\begin{array}{l}6.41^{a} \\
(.50)\end{array}$ & $\begin{array}{r}6.49^{a} \\
(.50)\end{array}$ & $\begin{array}{l}7.41^{a} \\
(.86)\end{array}$ & $\begin{array}{l}6.14^{a} \\
(.65)\end{array}$ \\
\hline population & $\begin{array}{c}11.95^{a} \\
(.51)\end{array}$ & $\begin{array}{c}12.05^{a} \\
(.51)\end{array}$ & $\begin{array}{c}14.24^{a} \\
(.97)\end{array}$ & $\begin{array}{c}10.48^{a} \\
(.60)\end{array}$ \\
\hline openness & $\begin{array}{l}0.26^{a} \\
(.03)\end{array}$ & $\begin{array}{l}0.27^{a} \\
(.03)\end{array}$ & $\begin{array}{l}0.54^{a} \\
(.06)\end{array}$ & $\begin{array}{l}0.03 \\
(.05)\end{array}$ \\
\hline distance & $\begin{array}{c}-2.94^{a} \\
(.17)\end{array}$ & $\begin{array}{c}-2.89^{a} \\
(.17)\end{array}$ & $\begin{array}{c}-2.30^{a} \\
(.26)\end{array}$ & $\begin{array}{c}-3.32^{a} \\
(.23)\end{array}$ \\
\hline labour freedom & $\begin{array}{l}0.02 \\
(.10)\end{array}$ & $\begin{array}{l}0.02 \\
(.10)\end{array}$ & $\begin{array}{l}0.13 \\
(.18)\end{array}$ & $\begin{array}{l}0.051 \\
(.13)\end{array}$ \\
\hline corruption & $\begin{array}{c}-0.29^{a} \\
(.08)\end{array}$ & $\begin{array}{r}-0.28^{a} \\
(.08)\end{array}$ & $\begin{array}{r}-0.10 \\
(.13)\end{array}$ & $\begin{array}{c}-0.45^{a} \\
(.10)\end{array}$ \\
\hline $\begin{array}{l}\text { Note: Note: }{ }^{a},{ }^{b} \text {, } \\
\text { respectively. Rob } \\
\text { The reported ela } \\
(2),(5),(8) \text { and }\end{array}$ & $\begin{array}{l}\text { nd }{ }^{c} \text { inc } \\
\text { st stand } \\
\text { icities c } \\
\text { 1) in ta }\end{array}$ & $\begin{array}{l}\text { cate sig } \\
\text { rd error } \\
\text { respond } \\
\text { le }(5) \text {. }\end{array}$ & $\begin{array}{l}\text { ance at } \\
\text { e reporte } \\
\text { the mod }\end{array}$ & $\begin{array}{l}\text { of } 1,5 \text { ar } \\
\text { n parent } \\
\text { umns }\end{array}$ \\
\hline
\end{tabular}



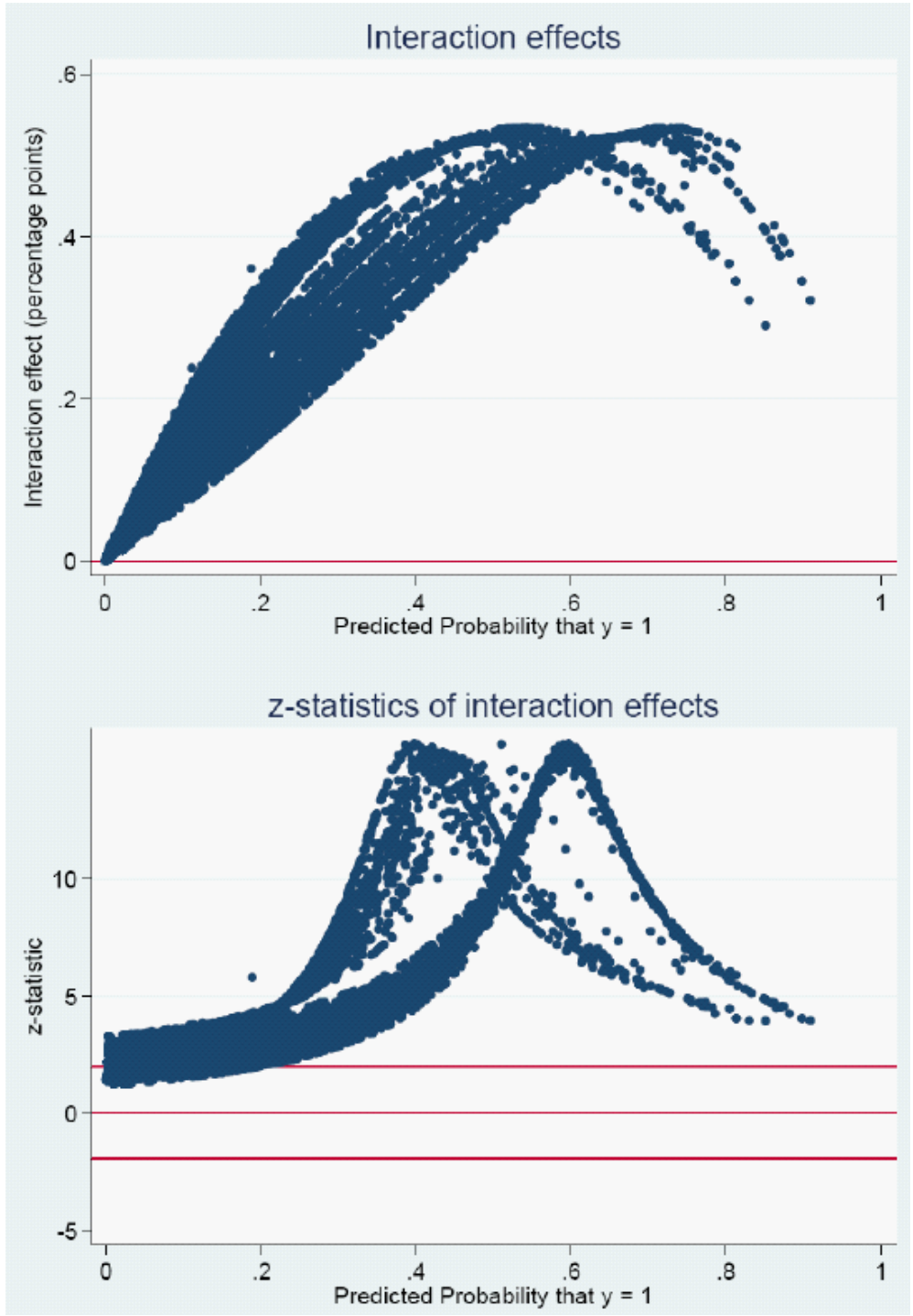

Figure 3: Interaction effect as a function of predicted probability 


\section{Robustness analysis}

In this section, we extend our analysis to consider various potential issues in connection to the robustness of the main results. For example, high income economies may contain more attractive targets for acquisition than lower income economies. To address this issue, we split the sample into OECD and non-OECD countries, and examine the effects of the corporate tax rate in both sub-samples. Columns (1) and (2) of table (7) present the results. The estimated coefficients on the tax rate in both sub-samples are as expected negative while the coefficients on the interaction term $\tau \times M \& A$ are positive. This finding confirms our main results presented in the previous section. The lower sensitivity of the location decision of M\&A investments to differences in the tax rate is robust to the distinction between OECD and non-OECD countries. The estimated coefficient on corruption in the non-OECD sample is negative and its magnitude becomes larger in comparison to the results obtained from the full sample (table 5). This indicates that a high level of corruption, particularly in non-OECD host economies, reduces the likelihood of locating a new affiliate.

One additional question is in relation to the size of the investment. Is the effect of the tax rate on the decision to locate a small investment different from the effect on the decision to locate a large investment? Based on the median of total fixed and intangible assets of the new foreign investment, we distinguish between large and small affiliates. Columns (3) and (4) of table (7) display the estimation results obtained from both sub-samples. The results do not suggest systematic differences between the responses of the location choice of large and small affiliates to corporate taxation.

As one could argue that large plant expansion is of a similar margin of investment as a Greenfield project, it is also of interest to account for potential effects of corporate taxation on the decision on plant expansion. We exploit information on the balance sheets of German affiliates abroad in order to broaden the definition of Greenfield investments in our analysis. Particularly, in addition to new Greenfield entrants, we consider a plant expansion measured as an increase in the total balance sheet of an already existing FDI affiliate of more than 50 percent as a Greenfield investment. The results based upon this broad definition of Greenfield investments are reported in column (5). The added Greenfield projects to the sample do not alter the tax effect.

In columns (6) to (9) of table (7), we control for further country characteristics. We include in column (6) the ratio of market capitalisation of listed companies to GDP to capture available potential targets for acquisition. Related to the issue of available targets, $\mathrm{R} \& \mathrm{D}$ considerations may trigger $\mathrm{M} \& \mathrm{~A}$ activities. If high tax economies are those economies associated with high ratios of R\&D expenditure to GDP, then the effect of the tax rate may to some extent capture R\&D opportunities. We address such a possibility by adding the R\&D intensity in the host economy to the set of controls. The results reported in column (7) show that the tax effect is robust to the inclusion of R\&D intensity.

In addition, one aspect that might derive the location decision of multinational firms is market opportunities not only in the host economy but also in the region. 
We construct a proxy for the regional market potential as the sum of the GDP of the countries that are located in the same geographical region. We define geographical regions based on the United Nations statistical classification. This market potential proxy is estimated to have a positive sign in column (8), but losses its significance when we also include the market capitalisation measure and the R\&D intensity (column 9).

While various studies find that the statutory corporate income tax rate has a high significant predictive power for the location decision, as for example in Buettner and Ruf (2007), for further insight we examine also the impact of the effective tax rate on the location decision. Unfortunately, data on the effective tax rate are available only for 32 countries (mainly OECD countries). According to our findings in column (10), the impacts of taxation on the location decision of FDI firms are very similar for both tax rate measures.

Hence, the results of the various specifications presented in this section are reassuring that the effect of corporate taxation on the location decision is significantly higher for Greenfield investments than for M\&A investments.

\section{Conclusion}

The empirical findings reported here contribute to our understanding of the role of taxation in determining the investment location decision by setting out reasons and providing empirical evidence why taxes matter. While most existing studies treat FDI as homogenous projects, our results distinguish between the compositions of FDI: M\&A versus Greenfield investments. We find that an increase in the statutory corporate income tax rate of 10 percent reduces the probability of choosing a country to host a Greenfield investment by about 6.4 percent. M\&A investments however are less sensitive to differences in international tax rates as indicated by a tax elasticity of -3.6 percent. This is consistent with a (partial) capitalisation of taxes in the acquisition price. Our findings are robust to a set of various specifications. Since in the period of our sample all FDI returns are exempted from German taxation, we could not test the effects of the home country tax system. With regard to policy implications, our finding indicates that tax reforms affect the composition of FDI as tax policies seem to differently affect the decision of M\&A and Greenfield projects. This finding

also contributes to a growing literature on possible differential implications of both modes of investment on the host economy. 


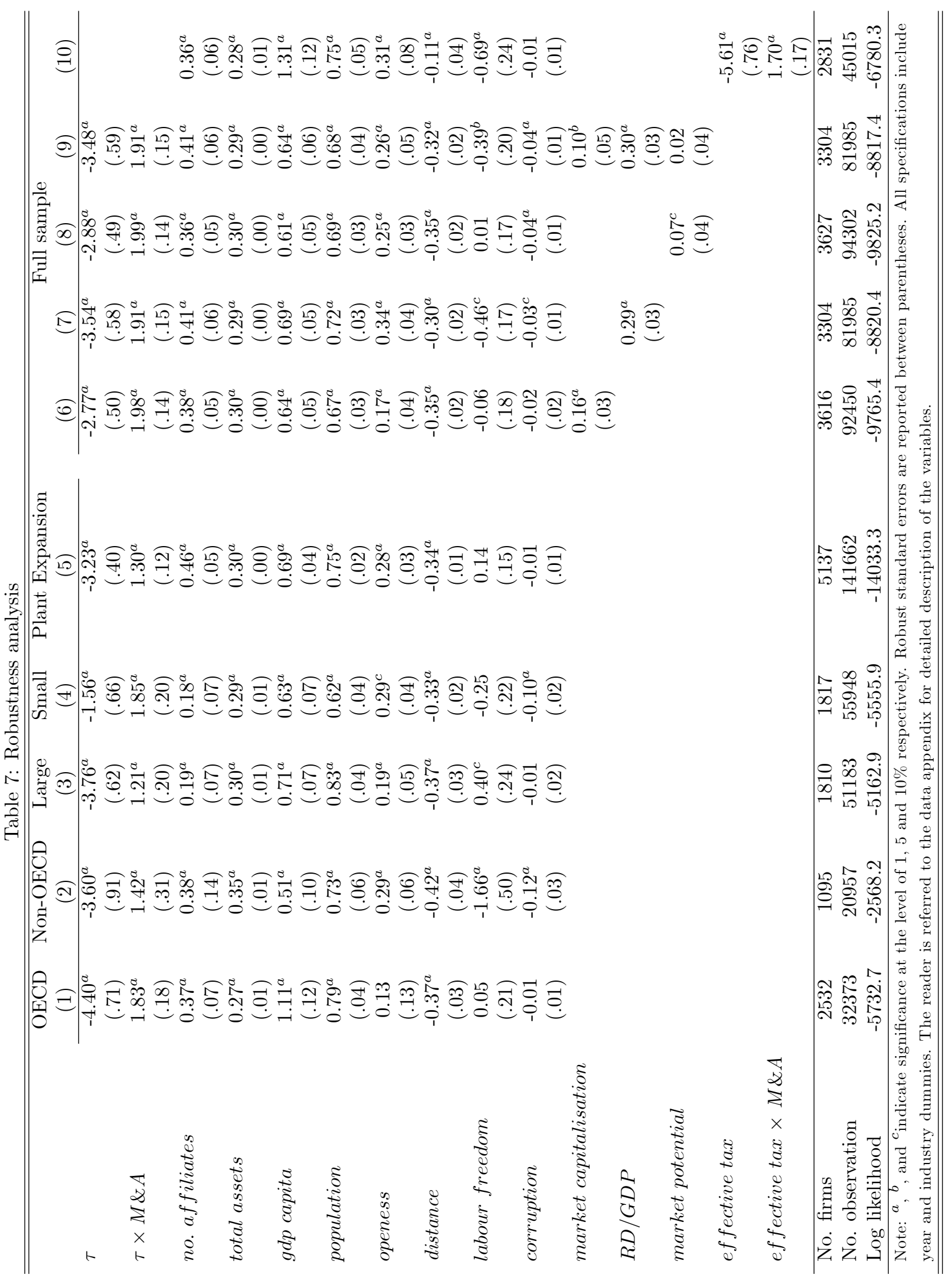




\section{References}

[1] Ai, C., and Norton, E. C. (2003). 'Interaction terms in logit and probit models, Economics Letters, vol. 80 (1), pp. 123-129.

[2] Andersson, T. and Svensson, R. (1994). 'Entry modes for foreign direct investment determined by the composition of firm-specific skills', Scandinavian Journal of Economics, vol. 96, pp. 551-60.

[3] Auerbach, A J., and Hassett, K. (1991). 'Taxation and foreign direct investment in the United States: a reconsideration of the evidence', NBER Working Papers Series, No. 3895.

[4] Balsvik, R. and Haller, S. (2007): 'Foreign firms and host-country productivity: does the mode of entry matter?', NHH mimeo.

[5] Becker, J. and Fuest, C. (2010): 'Taxing foreign profits with international mergers and acquisitions', International Economics Review, vol. 51, pp. $171-186$.

[6] Becker, J. and Fuest, C. (2008): 'Tax competition - Greenfield investment versus mergers and acquisitions', CESifo working paper No. 2247.

[7] Buettner, T., and Ruf, M. (2007). 'Tax incentives and the location of FDI: Evidence from a panel of German multinationals', International Tax and Public Finance, vol. 14 (2), pp. 151-164.

[8] Coeurdacier, N., Roberto, D,. and Aviat, A. (2009). 'Cross-border mergers and acquisitions and European integration', Economic Policy, vol. 24 (57), pp. 55-106.

[9] De Mooij, R A. and Ederveen, S. (2003). 'Taxation and foreign direct investment: a synthesis of empirical research', International Tax and Public Finance, vol. 10 (6), pp. 673-93.

[10] Desai, M., and Hines, J Jr. (2003). 'Evaluating international tax reform' National Tax Journal, vol. 3 (3), pp. 487-502.

[11] Devereux, M. (2007). 'The Impact of taxation on the location of capital, firms and profit: a survey of empirical evidence', Oxford University Centre of Business Taxation Working Paper, Nr. 07/02.

[12] Devereux, M. and Griffith, R. (1998). 'Taxes and the location of production: evidence from a panel of US multinationals', Journal of Public Economics, vol. 68, pp. 335-367.

[13] Devereux, M., Elschner, C., and Spengel, C. (forthcoming). Effective Tax Rates in the EU, 1998-200\%. Springer. 
[14] Dewit, G., Görg, H., and Montagna, C. (2009). 'Should I stay or should I go? A note on employment protection, domestic anchorage and FDI', Review of World Economics. vol 145 (1), pp. 93-110.

[15] Di Giovanni, J. (2005). 'What drives capital flows? the case of crossborder M\&A activity and financial deepening', Journal of International Economics, vol. 65, pp. 127-149.

[16] Djankov, S., Ganser, T., McLiesh, C., Ramalho, R., and Schleifer, A. (2009). 'The effect of corporate taxes on investment and entrepreneurship', American Economic Journal: Macroeconomics,

[17] Egger, P., Loretz, S., Pfaffermayr, M., and Winner, H. (2009). 'Corporate Taxation and Multinational Activity', Oxford University Centre of Business Taxation Working Paper, Nr. 09/04.

[18] Head, K., and Mayer, T. (2004). 'Market potential and the location of Japanese investment in the European Union', Review of Economics and Statistics, vol. 86 (4), pp. 959-972.

[19] Healy, P. M., and Palepu, K. (2007). Business Analysis and Valuation: Using Financial Statements, 4th ed. Mason, Ohio: Thomson Southwestern.

[20] Hines, J Jr. (1999). 'Lessons from behavioral responses to international taxation', National Tax Journal, vol. 52 (2), pp. 305-322.

[21] Hijzen, A., Görg, H., and Manchin, M. (2008). 'Cross-border mergers and acquisitions and the role of trade costs', European Economic Review, vol. 52, pp. 849-866.

[22] Huizinga, H. and Voget, J. (2009). 'International taxation and the direction and volume of cross-border M\&As', Journal of Finance, vol. 64 (3), pp. $1217-1249$.

[23] Huizinga, H. and Voget, J., and Wagner, W. (2008). 'International Taxation and Takeover Premiums in Cross-border M\&As', Oxford University Centre of Business Taxation Working Paper, Nr. 08/26.

[24] Javorcik, B., and Wei, S. (2009). 'Corruption and cross-border investment in emerging markets: firm-level evidence', Journal of International Money and Finance, vol. 28, pp. 605-624.

[25] Lipponer, A. (2008). Micro database direct Investment - MiDi. Deutsche Bundesbank, Frankfurt am Main.

[26] Markusen, J. (2002). Multinational Firms and the Theory of International Trade, Cambridge: MIT Press.

[27] Miller, T., and Holmes, K. (2009). 2009 Index of Economic Freedom, The Heritage Foundation and Dow Jones \& company, Inc, Washington and New York. Available online at: www.heritage.org/index 
[28] Mintz, J. and Weichenrieder, A. (forthcoming). The Indirect Side of Direct Investment: Multinational Company Finance and Taxation. MIT press.

[29] Modigliani, F. and M. H. Miller (1963). 'Corporate income taxes and the cost of capital: A correction'. American Economic Review vol. 53 (3), pp. 433-443.

[30] Neary, P, J. (2007). 'Cross-border mergers as instruments of comparative advantage', Review of Economic Studies, vol. 74, pp. 1229-1257.

[31] Nocke, V. and Yeaple, S. (2008). 'An assignment theory of foreign direct investment', Review of Economic Studies, vol. 75, pp. 529-557.

[32] Nocke, V. and Yeaple, S. (2007). 'Cross-border mergers and acquisitions versus Greenfield foreign direct investment: the role of firm heterogeneity', Journal of International Economics, vol. 72, (2), pp. 336-365.

[33] Raff, H., Ryan, M., and Stähler, A. (2009). 'The choice of market entry mode: Greenfield investment, M\&A and joint venture', International Review of Economics and Finance, vol. 18, pp 3-10.

[34] Swenson, D. (2001). 'Transaction Type and the Effect of Taxes on the Distribution of Foreign Direct Investment in the U.S', in James R. Hines, Jr., editor, International Taxation and Multinational Activity, University of Chicago Press, 89-108. 


\section{Appendix: Variable Definitions and Sources}

\begin{tabular}{|c|c|c|}
\hline Variable & Definition & Source \\
\hline$y$ & $\begin{array}{l}\text { a dummy that takes the value } 1 \text { for the chosen host } \\
\text { economy and the value zero otherwise }\end{array}$ & Deutsche Bundesbank \\
\hline$\tau$ & the statutory corporate income tax rate & $\begin{array}{l}\text { Mintz and Weichenrieder } \\
\text { (forthcoming) }\end{array}$ \\
\hline$M \& A$ & $\begin{array}{l}\text { a dummy that takes the value } 1 \text { if the investment } \\
\text { takes the form of M\&A and zero if the investment } \\
\text { is a Greenfield project }\end{array}$ & Deutsche Bundesbank \\
\hline no. affiliates & $\begin{array}{l}\text { the logarithm of the number of affiliates already } \\
\text { operating in the host economy }\end{array}$ & Deutsche Bundesbank \\
\hline total assets & $\begin{array}{l}\text { the logarithm of total fixed and intangible assets } \\
\text { invested by the parent firm in location } l\end{array}$ & Deutsche Bundesbank \\
\hline gdp capita & $\begin{array}{l}\text { the logarithm of gross domestic product per capita } \\
\text { based on PPP of the host economy }\end{array}$ & IFS of the IMF \\
\hline population & $\begin{array}{l}\text { the logarithm of the total number of inhabitants } \\
\text { in the host economy }\end{array}$ & IFS of the IMF \\
\hline openness & $\begin{array}{l}\text { the ratio of total trade (total imports plus total exports) } \\
\text { of the host economy to gross domestic product of the } \\
\text { host economy in current prices }\end{array}$ & IFS of the IMF \\
\hline distance & $\begin{array}{l}\text { the logarithm of the distance between Germany } \\
\text { (Hamburg) and the host economy }\end{array}$ & CEPII \\
\hline labour freedom & $\begin{array}{l}\text { the logarithm of the labour freedom component of the } \\
\text { Heritage index of economic freedom }\end{array}$ & Heritage Foundation \\
\hline corruption & $\begin{array}{l}\text { the Corruption Perception Index, redefined such that } \\
\text { a high value of this index indicates a high level of } \\
\text { corruption }\end{array}$ & $\begin{array}{l}\text { Transparency } \\
\text { International }\end{array}$ \\
\hline market capitalisation & $\begin{array}{l}\text { ratio of market capitalisation of listed companies } \\
\text { to gdp }\end{array}$ & WDI of the WB \\
\hline$R \& D / G D P$ & $\begin{array}{l}\text { the ratio of government expenditure on research } \\
\text { and development to gdp; percent }\end{array}$ & UNESCO Statistics \\
\hline effective tax & the effective average corporate income tax rate & $\begin{array}{l}\text { Devereux et al. } \\
\text { (forthcoming) }\end{array}$ \\
\hline market potential & $\begin{array}{l}\text { the logarithm of the sum of GDP of countries that } \\
\text { are located in the same region. Geographical regions } \\
\text { are defined based on the United Nations statistical } \\
\text { database available from: } \\
\text { http://unstats.un.org/unsd/methods } / \mathrm{m} 49 / \mathrm{m} 49 \text { regin.htm\#ftna }\end{array}$ & $\begin{array}{l}\text { IFS of the IMF and } \\
\text { UN statistics }\end{array}$ \\
\hline
\end{tabular}




\section{CESifo Working Paper Series}

for full list see www.cesifo-group.org/wp

(address: Poschingerstr. 5, 81679 Munich, Germany, office@cesifo.de)

3013 Frederick van der Ploeg and Steven Poelhekke, The Pungent Smell of "Red Herrings": Subsoil Assets, Rents, Volatility and the Resource Curse, April 2010

3014 Vjollca Sadiraj, Jan Tuinstra and Frans van Winden, Identification of Voters with Interest Groups Improves the Electoral Chances of the Challenger, April 2010

3015 Guglielmo Maria Caporale, Davide Ciferri and Alessandro Girardi, Time-Varying Spot and Futures Oil Price Dynamics, April 2010

3016 Scott Alan Carson, Racial Differences in Body-Mass Indices for Men Imprisoned in $19^{\text {th }}$ Century US Prisons: A Multinomial Approach, April 2010

3017 Alessandro Fedele, Paolo M. Panteghini and Sergio Vergalli, Optimal Investment and Financial Strategies under Tax Rate Uncertainty, April 2010

3018 Laurence Jacquet, Take it or Leave it: Take-up, Optimal Transfer Programs, and Monitoring, April 2010

3019 Wilhelm Kohler and Jens Wrona, Offshoring Tasks, yet Creating Jobs?, April 2010

3020 Paul De Grauwe, Top-Down versus Bottom-Up Macroeconomics, April 2010

3021 Karl Ove Aarbu, Demand Patterns for Treatment Insurance in Norway, April 2010

3022 Toke S. Aidt and Jayasri Dutta, Fiscal Federalism and Electoral Accountability, April 2010

3023 Bahram Pesaran and M. Hashem Pesaran, Conditional Volatility and Correlations of Weekly Returns and the VaR Analysis of 2008 Stock Market Crash, April 2010

3024 Stefan Buehler and Dennis L. Gärtner, Making Sense of Non-Binding Retail-Price Recommendations, April 2010

3025 Leonid V. Azarnert, Immigration, Fertility, and Human Capital: A Model of Economic Decline of the West, April 2010

3026 Christian Bayer and Klaus Wälde, Matching and Saving in Continuous Time: Theory and 3026-A Matching and Saving in Continuous Time: Proofs, April 2010

3027 Coen N. Teulings and Nick Zubanov, Is Economic Recovery a Myth? Robust Estimation of Impulse Responses, April 2010

3028 Clara Graziano and Annalisa Luporini, Optimal Delegation when the Large Shareholder has Multiple Tasks, April 2010 
3029 Erik Snowberg and Justin Wolfers, Explaining the Favorite-Longshot Bias: Is it RiskLove or Misperceptions?, April 2010

3030 Doina Radulescu, The Effects of a Bonus Tax on Manager Compensation and Welfare, April 2010

3031 Helmut Lütkepohl, Forecasting Nonlinear Aggregates and Aggregates with Timevarying Weights, April 2010

3032 Silvia Rocha-Akis and Ronnie Schöb, Welfare Policy in the Presence of Unionised Labour and Internationally Mobile Firms, April 2010

3033 Steven Brakman, Robert Inklaar and Charles van Marrewijk, Structural Change in OECD Comparative Advantage, April 2010

3034 Dirk Schindler and Guttorm Schjelderup, Multinationals, Minority Ownership and TaxEfficient Financing Structures, April 2010

3035 Christian Lessmann and Gunther Markwardt, Decentralization and Foreign Aid Effectiveness: Do Aid Modality and Federal Design Matter in Poverty Alleviation?, April 2010

3036 Eva Deuchert and Conny Wunsch, Evaluating Nationwide Health Interventions when Standard Before-After Doesn’t Work: Malawi's ITN Distribution Program, April 2010

3037 Eric A. Hanushek and Ludger Woessmann, The Economics of International Differences in Educational Achievement, April 2010

3038 Frederick van der Ploeg, Aggressive Oil Extraction and Precautionary Saving: Coping with Volatility, April 2010

3039 Ainura Uzagalieva, Evžen Kočenda and Antonio Menezes, Technological Imitation and Innovation in New European Union Markets, April 2010

3040 Nicolas Sauter, Jan Walliser and Joachim Winter, Tax Incentives, Bequest Motives, and the Demand for Life Insurance: Evidence from two Natural Experiments in Germany, April 2010

3041 Matthias Wrede, Multinational Capital Structure and Tax Competition, April 2010

3042 Burkhard Heer and Alfred Maussner, A Note on the Computation of the Equity Premium and the Market Value of Firm Equity, April 2010

3043 Kristiina Huttunen, Jukka Pirttilä and Roope Uusitalo, The Employment Effects of Low-Wage Subsidies, May 2010

3044 Matthias Kalkuhl and Ottmar Edenhofer, Prices vs. Quantities and the Intertemporal Dynamics of the Climate Rent, May 2010 
3045 Bruno S. Frey and Lasse Steiner, Pay as you Go: A New Proposal for Museum Pricing, May 2010

3046 Henning Bohn and Charles Stuart, Population under a Cap on Greenhouse Gas Emissions, May 2010

3047 Balázs Égert and Rafal Kierzenkowski, Exports and Property Prices in France: Are they Connected?, May 2010

3048 Thomas Eichner and Thorsten Upmann, Tax-Competition with Involuntary Unemployment, May 2010

3049 Taiji Furusawa, Kazumi Hori and Ian Wooton, A Race beyond the Bottom: The Nature of Bidding for a Firm, May 2010

3050 Xavier Vives, Competition and Stability in Banking, May 2010

3051 Thomas Aronsson and Erkki Koskela, Redistributive Income Taxation under Outsourcing and Foreign Direct Investment, May 2010

3052 Michael Melvin and Duncan Shand, Active Currency Investing and Performance Benchmarks, May 2010

3053 Sören Blomquist and Laurent Simula, Marginal Deadweight Loss when the Income Tax is Nonlinear, May 2010

3054 Lukas Menkhoff, Carol L. Osler and Maik Schmeling, Limit-Order Submission Strategies under Asymmetric Information, May 2010

3055 M. Hashem Pesaran and Alexander Chudik, Econometric Analysis of High Dimensional VARs Featuring a Dominant Unit, May 2010

3056 Rabah Arezki and Frederick van der Ploeg, Do Natural Resources Depress Income Per Capita?, May 2010

3057 Joseph Plasmans and Ruslan Lukach, The Patterns of Inter-firm and Inter-industry Knowledge Flows in the Netherlands, May 2010

3058 Jenny E. Ligthart and Sebastian E. V. Werner, Has the Euro Affected the Choice of Invoicing Currency?, May 2010

3059 Håkan Selin, Marginal Tax Rates and Tax-Favoured Pension Savings of the SelfEmployed - Evidence from Sweden, May 2010

3060 Richard Cornes, Roger Hartley and Yuji Tamura, A New Approach to Solving Production-Appropriation Games with Many Heterogeneous Players, May 2010

3061 Ronald MacDonald and Flávio Vieira, A Panel Data Investigation of Real Exchange Rate Misalignment and Growth, May 2010 
3062 Thomas Eichner and Rüdiger Pethig, Efficient Management of Insecure Fossil Fuel Imports through Taxing(!) Domestic Green Energy?, May 2010

3063 Vít Bubák, Evžen Kočenda and Filip Žikeš, Volatility Transmission in Emerging European Foreign Exchange Markets, May 2010

3064 Leonid V. Azarnert, Après nous le Déluge: Fertility and the Intensity of Struggle against Immigration, May 2010

3065 William E. Becker, William H. Greene and John J. Siegfried, Do Undergraduate Majors or Ph.D. Students Affect Faculty Size?, May 2010

3066 Johannes Becker, Strategic Trade Policy through the Tax System, May 2010

3067 Omer Biran and Françoise Forges, Core-stable Rings in Auctions with Independent Private Values, May 2010

3068 Torben M. Andersen, Why do Scandinavians Work?, May 2010

3069 Andrey Launov and Klaus Wälde, Estimating Incentive and Welfare Effects of NonStationary Unemployment Benefits, May 2010

3070 Simon Gächter, Benedikt Herrmann and Christian Thöni, Culture and Cooperation, June 2010

3071 Mehmet Bac and Eren Inci, The Old-Boy Network and the Quality of Entrepreneurs, June 2010

3072 Krisztina Molnár and Sergio Santoro, Optimal Monetary Policy when Agents are Learning, June 2010

3073 Marcel Boyer and Donatella Porrini, Optimal Liability Sharing and Court Errors: An Exploratory Analysis, June 2010

3074 Guglielmo Maria Caporale, Roman Matousek and Chris Stewart, EU Banks Rating Assignments: Is there Heterogeneity between New and Old Member Countries? June 2010

3075 Assaf Razin and Efraim Sadka, Fiscal and Migration Competition, June 2010

3076 Shafik Hebous, Martin Ruf and Alfons Weichenrieder, The Effects of Taxation on the Location Decision of Multinational Firms: M\&A vs. Greenfield Investments, June 2010 